$\mathbb{T}$ periodica polytechnica

Social and Management Sciences
14/2 (2006) 45-52
doi: 10.3311/pp.so.2006-2.01
web: http://www.pp.bme.hu/so
(C) Periodica Polytechnica 2006

RESEARCH ARTICLE

\section{Corporate social responsibility in the Countries of the Carpathian Euroregion}

Hajnalka Csáfor

Received 2007-09-14

\begin{abstract}
In the last years the expectations were also grown in the countries of the Carpathian Euroregion (Hungary, Poland, Slovakia, Romania, Ukraine), which require from the companies to be active - besides profitability and job creation - in solving ethical, social and environmental problems. The purpose of fostering corporations and also SMEs to integrate CSR activities into their operations cannot be achieved without raising awareness of the society and without effective governmental support, but the most crucial question concerning the expansion of corporate social responsibility is, whether players of the Economy of Carpathian Euroregion will recognize those forms of CSR that can be beneficial and easily harmonized with their business interests.
\end{abstract}

According to recent European research projects there is a growing demand for corporate social responsibility (CSR) in the states of the Carpathian Euroregion as well. In my paper I would like to collect the latest developments of CSR and to explore the future possibilities of developing CSR in the countries of the Euroregion. The main purpose of my paper will be to explore the way of learning CSR from other countries taking specialities of market, environment and society of the region into consideration.

\section{Keywords}

CSR · Carpathian Euroregion · social cohesion · sustainability $\cdot$ environmental sustainability

\section{Hajnalka Csáfor}

Department of Corporate Economics, Eszterházy Károly College, 3300 Eger, Eszterházy tér 1, Hungary

e-mail: hcsafor@ektf.hu

\section{Introduction}

CSR (Corporate Social Responsibility) continues to be an important tool of modern societies carried out by companies to deliver social cohesion and environmental sustainability on a voluntary basis - as well as economic development. The business concept of CSR is to be found among large companies in most countries around the world, but the increased efforts of the countries to the expansion of their competitiveness brought the need of spreading it among small and medium sized enterprises as well.

The concept of CSR was originally developed in the United States for corporations to strengthen their reputations by the society. According to the definition of CSRwire" "Corporate Social Responsibility aligns business operations with social values. CSR integrates the interests of stakeholders - all of those affected by a company's conduct - into the company's business policies and actions. CSR focuses on the social, environmental, and financial success of a company - the triple bottom line, with the goal being to positively impact society while achieving business success." By the definition of the European Commission CSR is "a concept whereby companies integrate social and environmental concerns in their business operations and in their interaction with their stakeholders on a voluntary basis" [9].

According to this European concept, the final long-term role of CSR of the corporations and SMEs is to get sustainable economic development by involving all the stakeholders from the governmental institutions through the civil organizations to the local communities. CSR is one of the tools which can help European countries to reach the Lisbon Strategy objective: to become the most competitive and the most dynamic knowledge based economy in the world by 2010 [11].

According to recent European research projects ${ }^{2}$ there is a 
growing demand for CSR in the countries of the Carpathian Euroregion (Hungary, Poland, Slovakia, Romania and Ukraine) as well. That is why I would like to explore the existing CSR practices in these states in my paper. I would like to collect the latest developments of CSR and to explore the future possibilities of spreading CSR with taking specialties of market, environment and society of given countries into consideration.

\section{The Carpathian Euroregion}

The first euroregion was established in Western Europe after World War II. in order to build trust and understanding between nations. Bringing Euroregions to Central and Eastern Europe was initiated by the East West Institute (EWI) which is a nonprofit research and policy institute that has sought to defuse tensions and conflicts, while building democracy and prosperity. The Carpathian Euroregion was born in 1993 with the membership of given counties of Hungary, Poland, Slovakia and Ukraine. Romania joined the Carpathian Euroregion in 1994.

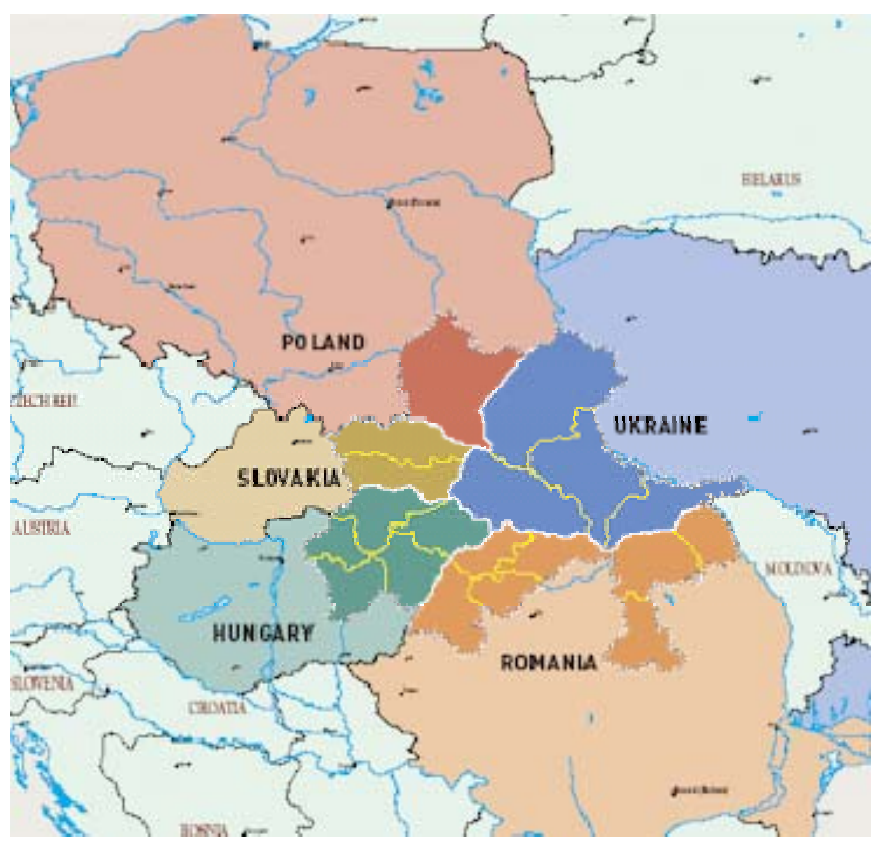

Fig. 1. The Carpathian Euroregion

The Euroregion is governed by the Council of the Carpathian Euroregion, which is an intergovernmental institution that includes representatives from each of the 19 administrative regions belonging to the Euroregion.

In the territory of the Euroregion 16 million people live, the majority of them in small towns and villages. These rural communities are isolated and their infrastructure is rather poor. Many of these small towns and villages are inhabited by minority ethnic groups that were cut off from their extended fam-

RARE project is researching the extent to which companies' voluntary activities in corporate social responsibility and related activities really contribute to sustainability and in particular to sustainability goals set by the European Union. 2005-2007 www.rare-eu.net ; Baseline Study on CSR Practices in the new EU Member States and Candidate Countries: funded by the European Commission and the United Nations Development Program. 2007 www.acceleratingCSR.eu ilies and traditional places of employment. While the national average for unemployment in the five countries is $10-20 \%$ the territory of the Carpathian Euroregion has unemployment rates between $15-30 \%$. Despite of the difficulties the people in the region are preserving. The region is rich in natural, cultural and architectural beauty, and the comparatively large number of universities and research centers are a great resource for the region's future [2].

\section{CSR Practices in the Five Countries of the Eurore- gion}

In the followings I would like to collect the characteristics of current CSR situation and existing CSR activities in the mentioned five countries of the EU. For giving this overall analysis of the countries of the Carpathian Region I used the results of my own research on CSR activities in North-Hungarian Region; the results of the Rhetoric and Realities EU research project [10]; the World Bank Study: What Does Business think about Corporate Social Responsibility? Part II. [19]; and the results of the UNDP-EU research project titled "Baseline study on CSR practices in the new EU member states and candidate countries" [14] completed with the information given by the keynote speakers of the international conference "The Way It Works" - Corporate Social Responsibility in the Carpathian Region held in September 2007 Presov, Slovakia [7], and some other sources listed among references. I focus on the following aspects: interpretation of CSR; CSR practices of the companies; CSR reporting and standards; the role of NGO's; Media; Education and CSR research projects; and finally the role of public administration in case of each countries of the Region.

\subsection{Interpretation of CSR}

Tab. 1. Interpretation of CSR in the countries of the Carpathian Euroregion

\begin{tabular}{|c|c|}
\hline Country & Interpretation of CSR \\
\hline Hungary & $\begin{array}{l}\text { Complying with the regulations, ethical business behaviour, } \\
\text { corp. philanthropy. }\end{array}$ \\
\hline & $\begin{array}{l}\text { The most important stakeholders: customers and local com- } \\
\text { munities. }\end{array}$ \\
\hline
\end{tabular}

Poland Ethical and transparent business behaviour.

The most important stakeholders: shareholders, employees and customers.

Slovakia Complying with the regulations, ethical business behaviour, corp. philanthropy.

The most important stakeholders: employees, customers and shareholders

Romania Corporate philanthropy.

The most important stakeholders: employees, NGOs and local communities.

Ukraine Responsible business behaviour (the concept is not really known),

The most important stakeholders: local communities and employees.

Source: self-developed 
Hungary became member state of the EU in 2004. The private sector accounts for over $80 \%$ of the GDP and foreign ownership and investment in Hungarian firms are widespread [19]. In Hungary - as in other Eastern European countries - there is only a short past of corporate social responsibility. The concept is not well known by the companies, mainly large corporations and subsidiaries of multinational companies adopt CSR policies, which are mainly concerned with their reputation and image. They believe that "socially responsible activities" are linked to complying with existing regulations and behaving ethically with the stakeholders [14]. The CSR concept is often identified improperly by corporate philanthropy.

Poland is a good example how to change from state-directed economy to a privately owned market economy. Today the country has modern economy and globalized commercial activities. Poland joined the EU in 2004. Majority of Polish companies believe that corporate social responsibility means the ethical and transparent business behaviour mainly with the shareholders, customers and employees which are the most significant stakeholders for the Polish companies.

Slovakia also had undergone a difficult transition from socialist economy to market economy. Slovak government made progress in 2001 in macroeconomic stabilization, but they pay the cost of increasing unemployment. In the last few years macroeconomic developments are favourable and with rapid growth, the decline of unemployment and easing inflation [14] Slovakia became the member of the EU in 2004.

In Slovakia most companies consider shareholders, customers an employees as well as top management as their most important stakeholders. Generally they do not consider the local communities to be stakeholders. According to the opinion of the Slovakian companies the socially responsible behaviour means to address the needs and concerns of the stakeholders, to behave ethically in business, to operate transparently and to comply with the regulations.

Romania joined the EU in 2007, and the Romanian economy is one of the fastest growing ones in the Union. The national currency is strong and the development of the economy is regarded by the analysts to be sustainable. In 2006 growth of the the GDP was $8.3 \%$ and the amount of foreign investments reached 8 billion Euros [16]. On the other hand corruption, bureaucracy and the large differences among salaries are still serious problems of the Romanian economy [8]. Companies - mainly multinationals - are more and more inclined in trying CSR programs, mainly corporate community investment programs. In Romania CSR concept had been imported through international companies that operate locally. Multinationals have the capacity to generate community interest for community projects through large visible initiatives. Target Groups are primarily children or persons with special needs, churches and monasteries, NGOs, employees and local communities as well [1].

Ukraine is situated at the transition point from wild capitalism to modern market economy, with many markets already matured and with identified market leaders. After the collapse of the Soviet Union, Ukrainian population started gradually adjusting to the notion of business in its modern meaning. CSR concept is far unknown in the country. There is strong economic growth in recent years and sound economic policies of last governments have provided enabling environment for corporate growth and economy's structural development, although a lot is still to be done [17]. Ukraine is the only member of the Carpathian Euroregion that is not yet member of the EU. There are examples of companies taking first steps in addressing issues of social importance beyond compliance. However, there are no formal strategies in regards to corporate citizenship and socially responsible business behaviour in Ukraine. Mainly large corporations apply CSR techniques. They regard their employees, customers and the local communities their important stakeholders [3].

\subsection{CSR Practices}

Tab. 2. CSR practices of the companies in the countries of the Carpathian Euroregion

\begin{tabular}{|c|c|}
\hline Country & CSR Practices \\
\hline Hungary & $\begin{array}{l}\text { Employee-protection, supporting education and sport, envi- } \\
\text { ronmental protection, codes of conduct, no anti-corruption } \\
\text { policies }\end{array}$ \\
\hline Poland & $\begin{array}{l}\text { Avoiding child labour, environmental protection, codes of } \\
\text { conduct, anti-corruption policies }\end{array}$ \\
\hline Slovakia & $\begin{array}{l}\text { Employee-protection, avoiding child labour, supporting local } \\
\text { communities, codes of conduct, anti-corruption policies }\end{array}$ \\
\hline Romania & $\begin{array}{l}\text { Community investment programs, large visible events, sup- } \\
\text { porting disfavored persons, education, sport, environmental } \\
\text { programs and churches }\end{array}$ \\
\hline Ukraine & $\begin{array}{l}\text { Supporting health care, education and local communities, } \\
\text { employee-protection, no environmental protection }\end{array}$ \\
\hline
\end{tabular}

Source: self-developed

Most of the Hungarian companies focus on the employeeprotection and organize or finance education for them. Environmental protection programs also exist, and recycling programs are also widespread. Many companies have codes of conduct, but there are no anti-corruption policies at all [19].

Hungarian SMEs are not familiar with CSR philosophy at all. The majority of the entrepreneurs have never heard about even the expression of CSR. However in spite of this fact a growing number of SMEs carry out socially and environmentally responsible activities related to their business strategies occasionally, without knowing that it is CSR. Mostly those CSR instruments are used among Hungarian SMEs, which do not cost anything for them and with which they are able to reduce their risks and costs, and are able to manage their reputation [10]. Among Hungarian society there is a low level of consumer awareness. The good examples of Western European countries also show that spreading corporate social responsibility cannot be achieved without the pressure of consumers. CSR activities of the companies do not play a significant role in decision making of the 
Hungarian consumers. The other characteristic feature of the Hungarian society is lack of commitment to the global social and environmental problems. There is a growing demand of CSR in Hungary as well. The Hungarian citizens are open to the problems of society and environment, but mostly just in mind and not in action. They are dealing with only those problems which endanger directly their local communities and environment [7].

Polish companies do not think that addressing stakeholder concerns, conducting public relations, and correcting social inequalities can be considered CSR. Polish companies consider complying with the legal framework and avoiding child labour the most important social role of a company. A majority of Polish companies have codes of conduct and anti-corruption policies are also widespread [19]. Most of the Polish companies are engaged in environmental projects, but half of them have no environmental certificate [14].

Most of the Slovakian companies are avoiding from the child labour - as in other European countries - and they consider protection employee health and protection environment to be important problems. Some Slovak companies are also engaged in social projects and they are also active in building local community relations. They support mainly health care institutions, education, and local community [19]. A majority of Slovakian companies have codes of conduct and anti-corruption policies are also widespread [14].

Most of all corporate community initiatives are event-based in Romania. At local level CSR practice is defined by individual values of the decision makers, and the way they perceive the role of the company as social change factor. The total investment of the firms in CSR activities in 2006 were over 10 million Euros. In Romania the most frequented fields of CSR are programs of social assistance, supporting relief agencies, corporate events, financing research projects in CSR, supporting disfavored persons, educational programs, programs for protecting environment and supporting sport clubs and events [1].

Ukrainian companies promote health care and local communities. They are the ones who donate local charities and they are also investing into training and education of their employees [3]. According to the United Nations CSR Study in Ukraine in 2005 on which activities were considered as CSR, 47,7\% of respondents cited charity, $32,1 \%$ said social programs, $29,6 \%$ developed working conditions of the staff and promoted their education, $18,4 \%$ said sponsorship events and TV programs, and only $12,9 \%$ caring for the environment [15].

\subsection{CSR Reporting and Standards}

Hungarian companies do not report their CSR activities, only 15 CSR reports have been released in 2006 [14]. Only 35 Hungarian corporations made environmental or sustainability reports - including CSR - at least once in the last 5 years. The first sustainability report was made in Hungary in 2002 [5]. ISO 14001 Standard is widespread in Hungary, but the Global Compact is not so popular.
Tab. 3. CSR Reporting and Standards in the countries of the Carpathian Euroregion

\begin{tabular}{|c|c|}
\hline Country & CSR Reporting and Standards \\
\hline Hungary & $\begin{array}{l}15 \text { CSR riports in } 2006 \\
\text { ISO 14001, no Global Compact }\end{array}$ \\
\hline Poland & $\begin{array}{l}10 \text { CSR in } 2006 \\
20 \% \text { ISO } 14001 \text {, Global Compact (just the multinational } \\
\text { companies) }\end{array}$ \\
\hline Slovakia & $\begin{array}{l}10 \text { CSR riports in } 2006 \\
20 \% \text { ISO } 14001,10 \text { Global Compact }\end{array}$ \\
\hline Romania & $\begin{array}{l}23 \text { CSR riports in } 2006 \\
\text { ISO 14001, no Global Compact }\end{array}$ \\
\hline Ukraine & $\begin{array}{l}\text { No CSR riport, just Sustainable Development (SD) riporting } \\
\text { ISO 14001, no Global Compact }\end{array}$ \\
\hline
\end{tabular}

Source: self-developed

$20 \%$ of the Polish companies are certified to ISO 14001 Standard and some of the largest companies are signatories to Global Compact. Only 10 companies issued CSR reports in 2006 [14].

In 2006 less than 10 companies issued CSR reports in Slovakia and these are not regular structured CSR reports. Slovak companies have not yet been reported by independent assurance companies. $20 \%$ of the companies are independently certified to the ISO 14001 Standard, but less than 10 to the Global Compact [14].

The communication of Romanian companies on their CSR practices depends on the internal motivation of the companies. In 200623 firms issued their CSR reports (programs) without signing the budgets. The implementation of standards as ISO 14001 or Global Compact is not widespread [18].

More and more Ukrainian companies are devoting resources and personnel to community engagement and CSR reporting. In response to growing interest in CSR in Ukraine, the United Nations launched its Global Compact Initiative in December 2005. The ISO 14001 and SA8000 Standards and Global Reporting Initiative is also known is Ukraine [13].

\subsection{Civil Sector}

The Civil Sector in Hungary is not really developed; most of the NGOs are funded by the state. They have no innovative partnership with the business sector, and do not transmit the real needs of the society [14].

In Poland NGOs are largely or wholly reliant on company and direct state financial support. According to the running research projects this situation will not change in the near future [14].

In Slovakia the campaigning NGOs are not independently funded, but there is a large number of international and national organizations promoting CSR. They concentrate on networking and exchanging information among companies [14].

Sustainable development - including CSR concept - is rather promoted by elites in Romania and NGOs with a weak feedback of the great majority of the society whose goal is still to reach income level that would allow a more decent way of living. NGOs 
Tab. 4. Civil Sector's role in CSR in the countries of the Carpathian Euroregion

\begin{tabular}{ll}
\hline Country & \multicolumn{1}{c}{ Civil Sector } \\
\hline Hungary & $\begin{array}{l}\text { Funded mainly by the state, no innovative partnership with } \\
\text { the business sector, does not transmit the real needs of the } \\
\text { society }\end{array}$ \\
Poland & $\begin{array}{l}\text { Funded mainly by the state, according to the research } \\
\text { projects that situation will not change in the near future }\end{array}$ \\
Slovakia & $\begin{array}{l}\text { Independent resources, many civil organizations focus on } \\
\text { CSR, transmit the needs of the society to the business sec- } \\
\text { tor } \\
\text { Romania }\end{array}$ \\
& $\begin{array}{l}\text { There are corporate resources, transmit the needs of the } \\
\text { society to the business sector (decision makers) }\end{array}$ \\
Ukraine & $\begin{array}{l}\text { Drivers of social dialogue, but there is a lack of prominent } \\
\text { NGOs and they have no strong influence }\end{array}$ \\
\hline
\end{tabular}

Source: self-developed

are primarily beneficiaries of the companies besides perceiving themselves as partners and trying to transmit the needs to the decision makers [1].

In Ukraine NGOs are the drivers of engaging corporate sector into social dialogue, but there is a lack of prominent NGOs engaging in this dialogue between companies and the civil society. There is relatively low level of NGOs' influence on decision makers at all levels of society [13].

\subsection{Media}

Tab. 5. The role of media in CSR in the countries of the Carpathian Euroregion

\begin{tabular}{|c|c|}
\hline Country & Media \\
\hline Hungary & $\begin{array}{l}\text { Does not publish CSR information (problem of the Hungar- } \\
\text { ian Media Act, price of a commercial advertisement, skepti- } \\
\text { cism) }\end{array}$ \\
\hline Poland & $\begin{array}{l}\text { Does not report CSR information of the companies (mainly } \\
\text { negative news) }\end{array}$ \\
\hline Slovakia & Active in reporting CSR information \\
\hline Romania & No positive attitude of the Media \\
\hline Ukraine & Critical attitude to CSR information (skepticism) \\
\hline
\end{tabular}

Source: self-developed

One of the things which make it more difficult to get information about CSR activities of the corporations in Hungary is the problem of Media. According to the current Media Act, the corporations have to pay the rate of the commercial advertisement even for the public-purpose announcements or news. If a broadcasting company reports - among the news as factual report some CSR activity (for example a charitable event) with mentioning the name of the responsible company it can calculate on 20-30 thousand Euro fine from the National Radio and Television Commission, because the announcement is identified as a hidden advertisement [16]. Because of this regulation - which does not meet the EU directive of media regulation - the responsible companies have no chance to publish their CSR activities without paying the high rate of commercial advertisement. On the other hand there is a growing number of articles in connection with CSR on websites and in newsletters.

In Poland Media does not report social responsible activities of the companies. The CSR and sustainable consultancy have no active market [14].

In Slovakia the National Media is active in publishing CSR articles and news [19].

In Romania there are a lot of visible national events related to CSR concept: conferences, Galas, PR-Awards, there are thematic homepages ${ }^{3}$, but the mass media reaction is to the social initiatives is not positive and cooperative [1].

In Ukraine there are close links between economics and politics which make difficult to communicate CSR in mass media. There are critical publications linked with political motives, and there is no trust to mass media in Ukraine [3].

\subsection{Education and CSR Research}

Tab. 6. Education and CSR Research in the Countries of the Carpathian Euroregion

\begin{tabular}{|c|c|}
\hline Country & Education and CSR Research \\
\hline Hungary & $\begin{array}{l}\text { Business ethic courses, number of CSR research projects } \\
\text { are relatively low }\end{array}$ \\
\hline Poland & $\begin{array}{l}\text { No CSR in educational programs, only a few CSR research } \\
\text { projects }\end{array}$ \\
\hline Slovakia & $\begin{array}{l}\text { Special CSR courses, large number of CSR research } \\
\text { projects }\end{array}$ \\
\hline Romania & $\begin{array}{l}\text { No CSR and business ethics in the educational programs at } \\
\text { all, mainly civil organizations run CSR research projects }\end{array}$ \\
\hline Ukraine & $\begin{array}{l}\text { No CSR and business ethics in the educational programs at } \\
\text { all, but rapid development can be expected }\end{array}$ \\
\hline
\end{tabular}

Source: self-developed

Almost at all the faculties of economics in the Hungarian universities there are business ethic courses, but the number of research projects on CSR is relatively low [7].

There are no educational programs in Polish universities related to CSR, and the number of research projects in the topic of CSR is relatively low [14].

Slovakian universities offer specific courses in the field of CSR, and a large number of academic researches are available [12].

Romanian universities do not offer any CSR or business ethics program. Mainly civil organizations run CSR research projects [12].

Ukrainian universities do not offer any CSR or business ethics program, but rapid development can be expected because education is a booming industry in Ukraine, and companies are addressing social issues through interaction with state-run educational system; they try to raise importance of private sector in education [15].

\footnotetext{
3 www.csr-romania.ro; www.responsibilitatesociala.ro;
} www.donatiionline.ro; www.dezvoltaredurabila.ro; etc. 


\subsection{Public Administration}

Tab. 7. The Role of Public Administration in the Countries of the Carpathian Euroregion

\begin{tabular}{ll}
\hline Country & \multicolumn{1}{c}{ Public Administration } \\
\hline Hungary & $\begin{array}{l}\text { CSR decision-making of the government, Ministry of Econ- } \\
\text { omy and Transport - CSR director, incentives are planned } \\
\text { Poland }\end{array}$ \\
& $\begin{array}{l}\text { Strong SD strategy, not any governmental department re- } \\
\text { lated to CSR, not incentives for building partnership relations } \\
\text { with the private sector }\end{array}$ \\
Slovakia & $\begin{array}{l}\text { SD strategy, wide range of legislation to promote CSR, not } \\
\text { any governmental department for CSR }\end{array}$ \\
Romania & $\begin{array}{l}\text { Not any governmental department for CSR, not governmen- } \\
\text { tal incentives }\end{array}$ \\
Ukraine & $\begin{array}{l}\text { Not any governmental department for CSR, local govern- } \\
\text { ments are active in the field of CSR, low level of legislation } \\
\text { to promote CSR, rapid changes of legislation }\end{array}$ \\
\hline
\end{tabular}

Source: self-developed

The role of the national government in developing CSR - similarly to the other examined countries - was not a frequented topic in Hungary, but recently growing number of companies recognize the importance in governmental decision-making to promote CSR, in giving rate and tax allowances, in labour law reform, in supporting national CSR research projects or in establishment of CSR-awards and reconcilements. The governmental emphasis is on providing incentives for responsible production and responsible business behaviour without any interventions to preserve their voluntary nature. The Minister of Economy and Transport appointed a CSR director in 2006. Governmental encouragement helps to the Hungarian corporations in shaping partnership relations in order to make their social responsibility more successful and more targeted [5]. Besides the adaptation of EU directives there are also Hungarian legislative initiatives and proposals in connection with corporate responsibility concerning the Hungarian Public Procurement Act [7].

The political environment is underdeveloped in Poland in connection with CSR, there is no any governmental department dealing with CSR issue. The Sustainable Development National Strategy has been published and that is the main strength of this domain. The government doesn't build partnership relations with the private sector and NGOs in order to raise awareness and understanding the social and environmental problems and ethical issues [14].

The national government has published a Sustainable Development Strategy and there is also a wide range of legislation to promote CSR in Slovakia. There is not any CSR related governmental department in Slovakia [14].

There are deficiencies in the interaction with public authorities, and the national government has not yet named a governmental department leading the CSR issues, that makes difficult spreading CSR in Romania [18].

The National Government of Ukraine is keen to support the realization of Global Compact principles by the private sector and the creation of an enabling environment for its further promotion [15]. Increasing activity of local authorities can be experienced in connection with CSR issues, but the low level and selective law enforcement (rapid and often changes of laws) makes justification of CSR business case very hard [17].

\section{Common CSR factors in the Carpathian Euroregion}

There are common factors which are similar in the countries of the Carpathian Euroregion in connection with CSR. Naturally each country has also different characteristics in national and cultural context, which they should take into the consideration in creating their national CSR strategy. The Carpathian Region is a specific area with significantly different economic, cultural, social, demographic and ethic characteristics in comparison to other areas of the abovementioned countries [12].

Nevertheless, in the following I try to emphasize common factors and to give a list of them in order to give overall recommendations for developing CSR in the Region, which is one of the objectives of this paper:

- Planning economy without taking the needs of the society and the environment into consideration has the result of serious inefficiencies in the Region.

- During the socialism in all of the countries there were generous social benefits. As a heritage of welfare economy there can be felt skepticism from the side of the business sector regarding the efficiency of public services as tax revenue allocation.

- The rapid political changes in the countries of the Region in the 90 s created a strong distinction between the "dark communism" and the "sunny capitalism", which led to negative image of the Trade Unions, public works, or even the older generation.

- All of the countries have strong economic dependencies on different business sectors which are dominant. The development of CSR in these countries primarily depended on the contribution of the companies of these dominant factors.

- CSR practices are common among large corporations an almost all the countries of the Region. However SMEs play important role in the economy of these countries they are the biggest employers and the joint impact of their operations is also considerable.

- Corporations of the Region do not use a wide range of the CSR practices, and hoc philanthropic activities are typical.

- Many of the corporations apply CSR only for marketing and PR purposes and the long-term thinking is missing from their CSR activity.

- The number of the companies in the Region that have certified ISO 14001 or Global Compact standards is not high. 
- Only a few companies of the Region report their CSR activities, and the issued reports are mainly not regular structured CSR reports.

- The awareness of the society in the Region is on a rather low level. While the consumers and the business partners do not force business actors to reduce or compensate negative effects of their economic activities, we cannot expect self-restrictive business operation from them. The CSR practices of WesternEuropean countries also show that spreading corporate social responsibility cannot be achieved without the pressure of consumers.

- NGOs of the Region do not use efficiently their capacities to play their roles in social dialogue between society and the business sector.

- The attitude of the media to CSR issues in the region is not satisfying and positive.

- The issues of CSR do not appear as separate subjects in educational programs, but in most of the countries environmental, sustainable development, and other business ethics related issues are built into the programs of grammar schools and higher educational institutions.

- The national governments of the countries issued Sustainable Development Strategies, but the governmental decision makings and the legal systems of the countries do not give incentives to CSR actions.

- The governmental departments dealing with CSR issues are missing from almost all of the countries of the Region.

\section{Recommendations for developing CSR in the coun- tries of the Carpathian Euroregion}

These recommendations are addressed to the business sector, civil society organizations, public administration, media and the education systems of each country based upon the suggestions of thematic working groups of "The Way It Works" Conference in Presov, Slovakia [12].

One of the most important tasks of the business sector is to understand the real needs in the community, and working for creative and innovative solutions to build up partnership relations with NGOs in order to make their CSR activities more effective. The role of large corporations is to promote SMEs' involvement in CSR with relevant information (good practices, research, media). They should spread CSR concept via donor company events as well, like open doors day where lots of people and the media visit the company premises. The companies should conduct quantitative research projects of their CSR activities to demonstrate their benefits to the other businesses, and they should also monitor the impacts of their CSR events beyond just the quantitative aspects. They should develop a thorough follow-up system for supported projects.
The members of the business sector should also share their experiences on CSR with other businesses e.g. within business associations. They should engage media, and make effort to publish the achievements of CSR activities and to use arguments of competitive advantage and reputation building (mitigating reputation risk) to make the business case for CSR. Besides giving financial support the companies' managements should involve employees in CSR activities whenever it is possible. Finally the most important thing in the CSR activity of the business sector is the authenticity, which should be put high priority in each case.

Similarly to the one of the most important tasks of the business sector of the Carpathian Region, civil society organizations also should build up creative and innovative partnership with the business sector. NGOs understanding the real needs of the society can be those actors in the economy that transmit these needs to the decision makers of the companies. They should consider not to ask solely for money, but to offer some kind of service for the company. NGOs should also guarantee visibility of the projects they run, and to present the results of their work. Citizen groups should build their accountability to be trustworthy for the business.

NGOs also have important role in engaging media with building good relationship with them on local level. They should promote and disseminate feedback of CSR projects with mentioning good and bad experiences as well.

With promoting specific issues the civil society organizations make it possible for companies to join. They can also help to create CSR partnerships with long-term sustainability. NGOs can have important role in organizing and to contribute public debate about CSR on all levels, and to promote dialogue on CSR related issues - everything should be agreed through the dialogue.

NGOs should always take care about not to make the business feel to be forced to do something, the business must feel free in promoting them.

The most important role of the public administration (national and local governments) in the countries of the Region is to provide endorsement or even legislative support to CSR activities with preserving CSR's voluntary nature. Local governments also can help to make better dialogue between all actors under the umbrella of local administration. They should organize cross-sector groups to conduct community needs assessment and they should organize and contribute to public debate about CSR concept all - especially political - level as well.

Local governments also have a role to play in raising awareness, namely transmitting CSR campaigns of the European Commission to the citizens and also to the companies of the Region with even the help of the local media. They should enlighten and promote feedback of projects, promote good examples, ideas, benefit of CSR for business with operating in a socially responsible way.

The most important role of the media is in communicating the right message about the CSR initiatives generated by the three 
partners (business, NGOs, national and local governments) and sustaining the concept in the community. The media has also a very important task in raising awareness of CSR with giving publicity to good examples and benefits of being responsible. The media should promote the value of volunteering as an important aspect of CSR beyond philanthropy. Above all, the media has a role to play in organizing public debate about CSR on all levels, and in promoting good and bad experiences of CSR projects with emphasizing the benefits of CSR activities especially for business and all the society.

The most important role of educational systems of the countries of the Region is implementing CSR concept according to the specificiality of Eastern European Countries, and developing proper education in this regard on high school and university level as well. The educational institutions have also a leading role in managing scientific research projects on CSR, and creating measurements (qualitative and quantitative ones) for evaluating CSR performance. They should also continuously disseminate the results of their CSR research in order to demonstrate its benefits to all parties involved. They should publish more information about CSR, especially about CSR activity of SMEs with mentioning the good examples of the neighbouring countries that are on higher level in implementing CSR. The comparison of legislation systems (taxes and law reforms, etc.) given by researchers would provide useful information especially to the public administrations, but to all parties as well.

Besides the scientific research, the education system has an important role in raising awareness of the young generation with building sustainability and responsible thinking into various subjects of their curricula.

\section{Conclusion}

We can declare the unique and crucial importance of each sector of society - including business sector (large corporations and also SMEs), public administration (governmental departments and local governments), NGOs, educational systems, and mass media - in implementing the CSR concept as a tool for economic and social development of the Carpathian Euroregion. Despite the growing interest in corporate social responsibility in the countries of the Region, there is still an urgent need for creation of conditions suitable for gradual takeover and implementation of existing CSR practices that proved to be successful in specific conditions of peripheral and less developed regions of these countries [12].

\section{References}

1 Bresovan I, Association for community relations Romania: Country Report about Romanian CSR, Unknown Month 25.

2 Broschure of the Carpathian foundation, Szeged, 2003. Factory Creative Studio.

3 Business Ukraine: CSR: Doing the Right Thing, 23. 04. 2007, available at www. businessukraine.com.ua/csr-doing-the.

4 Commission of the European Communities:, Vol. 136, 2006.
5 Demos Magyarország Alapítvány: Több, mint üzlet: Vállalati társadalmi felelösségvállalás, 2006, available at www. demos.hu.

6 Euractive: Dübörög a román gazdaság, 29. 12. 2007, available at www. eurohirek.hu.

7 Feketéné Csáfor, Hungarian Distinctiveness of CSR in Comparison with EU Practices, Unknown Month 22.

8 Magyar Kereskedelmi Iroda: Románia gazdasága: összefoglaló tájékoztató, 2005.

9 Office for official publications of the European Communities: Promoting a European framework for corporate social responsibility, Green Paper, 2001.

10 Rhetoric and realities: Analyzing Corporate Social Responsibility in Europe (RARE) research project funded within the Sixth Framework of the EU: Survey of SMEs 2005.

11 Szlávik J, Fenntartható környezet- és eröforrás-gazdálkodás, KJK, Budapest, 2005.

12 Declaration of Participants of the International Conference organized by the Carpathian Foundation, Unknown Month 26.

13 Ukraine CSR Bulletin, available at www. csrukraine.org .ua. downloaded: 01. 10. 2007.

14 United Nations Development Program and European Commission: Baseline Study on CSR Practices in the New EU Member States and Candidate Countries, 2007, available at http://ec.europa.eu/employment_ social/soc-dial/csr/pdf. Dowloaded: 28. 09. 2007.

15 United Nations in Ukraine: Report on CSR and Global Compact Forum in Ukraine 2006, available at www. un.orgua/eu/news/2006-01-03. downloaded: 28. 09. 2007.

16 Üzleti etika: CSR és média- konferencia a Pannon szervezésében 2006, available at www.uzletietika.hu/cikk.php?article=289. downloaded: 12 . 07. 2006.

17 Vorobey V, Corporate Social Responsibility in Ukraine 2004, available at http: //www.csr.org.ua/. downloaded: 06. 10. 2007.

18 Vuta M, Verboncu I, Duca I, Stefanescu A, Gheorghina R, Dudian M, Ciocirlan D, Dobrin C, Hrisanta Dobre M, The Corporate Social Responsibility Practices in Romania in the context of sustainable development principles. ERSA Congress Paris August 29- September 2007.

19 World Bank Study: What does Business think about Corporate Social Responsibility?, Brussels, 2005, available at www.ivsz.net/resource.aspx? ResourceID=romhuitforum_romangazdtaj. Part II. 